\title{
DOI:https://doi.org/10.24297/jssr.v18i.9123
}

\section{Availability And Utilization of Physical Facilities as Correlates of Students' Academic Performance in Electrical Installation and Maintenance Work Practice in Technical Colleges in Ekiti State}

\author{
${ }^{1}$ Adameji, James Oluwasola, ${ }^{2}$ Prof. Okoye, Kelechi Reko E. \\ Department of Technology and Vocational Education,
}

Nnamdi Azikiwe University, Awka

\begin{abstract}
;
This study determined the availability and utilization of physical facilities as correlates of students' academic performance in electrical installation and maintenance work practice in technical colleges in Ekiti State. Four research questions and three null hypotheses guided the study. Descriptive survey and correlational research designs was used for the study. Eight hundred and fifty-three (818 students and 35 teachers) of electrical installation in the six government-owned technical colleges in Ekiti State were studied without sampling. The Instruments for data collection included checklist, structured questionnaire and performance test. The reliability of the performance test was determined through split-half technique. Spearman-Brown formula was employed for reliability coefficient computation which yielded a reliability coefficient of 0.905 . Percentage, mean, standard deviation and Pearson Product Moment Correlation coefficient were used to answer research questions. The ttest statistical tool was used to test the null hypotheses relating to utilization of instructional facilities while Pearson Product Moment Correlation coefficient was used to test the null hypotheses relating to physical facilities and students' academic performance. Findings revealed that majority of physical facilities are available for electrical installation and maintenance work practice in technical colleges in technical colleges in Ekiti State. The study also revealed that there is high positive relationship of 0.61 existing between students' utilization of physical resources and their academic performances in electrical installation and maintenance work practice in technical colleges in Ekiti State. The study concluded that the level of availability and utilization of physical facilities for electrical installation and maintenance work practice in technical colleges in technical colleges in Ekiti State is not adequate for equipping students with practical skills for self-reliance. The study recommended among others that owners of technical colleges in Ekiti State should adequately provide relevant physical facilities for effective teaching of electrical installation and maintenance workshop practices.
\end{abstract}

Key Words: Availability, Utilization, Physical Facilities and Academic Performance,

\section{Introduction}

Education has great potentials for the transformation of the individuals and the society as it is one of the major yardsticks for measuring the progress, civilization and development of mankind in any organized society. No wonder, Onokpaunu (2016) considered education as an indispensable input for national development and an avenue for empowering citizens of any nation. Hence, education has continued to be important and this is why there has been a growing concern in recent years about the quality of education (including technical education) that is offered in the nation's educational institutions.

Technical education is an aspect of educational process involving, in addition to general education, the study of technologies and related sciences and acquisition of practical skills, attitudes and knowledge relating to occupations in various sectors of economic and social life (Federal Republic of Nigeria- FRN, 2013). Some of the subjects/trades in technical colleges include auto mechanics, mechanical trades, wood trades, building trades, welding, electrical installation and maintenance work practice, electronic work and appliances repair among others (FRN, 2013). These trades are designed to produce a knowledge based and practically skilled individuals who will be self-reliant.

Electrical Installation and Maintenance Work Practice (EIMWP) is a programme introduced by way of practical exercise, the maintenance of electrical system and circuits, electrical installation, inspection and test procedure. Electrical installation and maintenance work practice in technical colleges, according to the National Board for Technical Education (NBTE) (2007) consists of domestic electrical installation, industrial installation, cablejointing and battery charging and repairs, among others. The NBTE stated that the main objectives of EIMWP 
are to: secure employment either at the end of the whole course or after completion of one or more modules of employable skill; and pursue further education in advance technical programme in tertiary technical institutions. In order to implement and achieve these objectives, the NBTE stipulates the minimum standards of course offering and instructional facilities (physical facilities) that need to be available for the establishment and administration of electrical installation and maintenance work practice in technical colleges at that level.

Physical facilities refers to the school plant, that is, the school buildings, classrooms, library, laboratories, toilet facilities, offices and other materials and infrastructures that would likely motivate students towards learning (Akomolafe \& Adesua, 2016). Physical facilities for technical education encompasses all classrooms, workshops, laboratories, electrical/electronic instruments among others which enable the learner to learn properly and perform academically well (Ogbu, 2015). School physical facilities provide and maintain safety, cleanness, and creativity learning environments to the students which encourage students to perceive high achievements and outcome (Nepal \& Maharjan, 2015).

Availability, according to Joseph and Philias (2011) is defined as general characteristic of a resource that is committable, operable, or usable upon demand to perform its designated or required functions. Thus, to enhance effective teaching and learning of electrical installation and maintenance work practice in technical colleges in technical colleges, physical facilities must be available and fully utilized. Utilization is a noun form of adverb 'utility' which means the act or process of using a particular thing, idea or method for the actualization of a purpose. Utilization of physical facilities refers to the equitable use of facilities by technical colleges for effective implementation of school curriculum. Effective usage of physical facilities is supposed to bring about skill development and acquisition among the electrical installation and maintenance work practice in technical colleges among students in the technical colleges. Maduewesi (2010) noted that availability and utilization of physical facilities have been positively correlated to good performance in examinations while poor performance has been blamed on inadequacies.

The academic performance of technical college students in electrical installation and maintenance works in Nigeria over the years has been far from impressive. For instance, Eze and Osuyi (2018) revealed that the percentage of students' failure in electrical installation and maintenance in NABTEB examination has increased from 96 percent in 2012 to 100 in 2014. Similarly, the result of NABTEB examinations shows poor performance of technical college students in EIMW in Ekiti State. Analysis of NABTEB conducted examinations in May/June for EIMW from 2015 to 2017 revealed failure rates of $76.35 \%$ in $2015,67.12 \%$ in 2016 and $56.10 \%$ in 2017 . This situation could make it difficult to produce future competent technologists who are highly needed in business organizations. Okoh, Ayowei and Onyeluka (2011) attributed the poor performance of technical college students in EIMW to many variables such as inadequate supply of instructional materials and technical workshops, insufficient or lack of physical and training equipment, tools, and consumable among others.

Moreover, in the technical colleges, electrical installation and maintenance work practice in technical colleges is taught with emphasis geared towards training the students on acquisition of appropriate knowledge and the necessary practical skills in the trade through the utilization of appropriate physical facilities by technical educators. That is to say, for effective teaching and learning of electrical installation and maintenance work practice, physical facilities are necessary. Lemo and Olakotan (2016) noted that using facilities during teaching and learning would equip the students with adequate psychomotor skills and as a result stimulate their interest to participate in the teaching and learning activities thereby promoting effective teaching and learning.

The physical facilities on could help to facilitate teaching and learning and as such could be used to influence students' academic performance and effect permanent change in behavior in them. In view of this, Oyeyemi (2010) maintained that instructional facilities have positive link with students' academic performance and their capabilities when they leave school. However, a cursory look at the nation's technical colleges seems to show that the colleges are struggling with limited and outdated physical facilities. Similarly, the researcher observed that many of the Technical Colleges in Ekiti State do not have physical facilities related to the technical subjects/trades offered in the college especially EIMWP. It is pathetic to see teachers delivering instructions in the classroom on technical education trades; mostly electrical installation and maintenance work practice without utilizing appropriate facilities. Jin support of the researcher's clain, Joseph and Phillias (2011) reported low level availability of physical facilities in schools in Ekiti State. Uzochima (2013) on the other hand observed 
that though physical facilities were available, but they are not adequate in the colleges of education while Okoli, Uzoagulu and Okoli (2018) found a state of gross inadequacy in the workshop facilities available for instruction in technology education programmes in universities These findings simply means that mastery of practical application and skills in EIMWP concepts might not be fully achieved by students with physical facilities being available. The FRN (2013) asserted that the provision and use of available physical facilities for teaching will lay sound bases for scientific and reflective thinking among students irrespective of gender and location of institution.

Gender refers as a social or cultural construct, characteristics, behaviours and role which society ascribes to males and females (Igbo \& Vincent, 2014). In recent times gender related issues in EIMWP has continued to receive serious attention judging by the number of studies done to that effect. Babajide (2010) opined that science and technical trades such as EIMWP are given masculine outlook by educational practitioners. In addition to this, the study by Ogunleye (2002) showed that students' performance in EIMWP depends on gender. Nwosu (2018) found that students' acquisition of EIMWP skills are not gender specific. Another influencing factor in the context of availability and utilization of physical facilities in teaching and learning is location of institution. School location could be a factor in determining students' skill acquisition in EIMWP. It is assumed that school location has far reaching effect on the provision of instructional facilities and even distribution of amenities in schools. Based on this background, this study was carried out to determine the availability and utilization of physical facilities as correlate of students' academic performance in electrical installation and maintenance work practice in technical colleges in Ekiti State.

\section{Statement of the Problem}

Technical college plays a major role in the production of competent manpower for electrical industries. In teaching and learning EIMWP in technical colleges, physical facilities stimulate and improve students' academic performance. However, the advantages of physical facilities have not reflected in the students' academic performance in the subject as the academic performance of technical college students in electrical installation and maintenance works in Ekiti State over the years has been far from impressive. The analysis of result of NABTEB examinations conducted in May/June on electrical installation and maintenance work from 2015 to 2017 revealed failure rates of $76.35 \%$ in $2015,67.12 \%$ in 2016 and $56.10 \%$ in 2017 respectively and this poor performance may be because of the dearth of physical facilities in the nation's technical colleges.

Similarly, observational trip to some Technical Colleges in Ekiti State by the researcher revealed that most electrical installation teachers teach the students with limited physical facilities. It was assumed that the limited use of physical facilities for teaching could not help students perform better in any of the National Business and Technical Examination Board (NABTEB) examinations. This situation could also result in poor academic performance of students in EIMWP at Technical Colleges. The unsatisfactory performance of technical college students in EIMW is causing great concern in recent times for teachers. If this continues, it could affect the students' prospective occupations in industries or private establishments on graduation. This study therefore, the study investigated the correlation between availability and utilization of physical facilities and students academic performance in Electrical Installation and Maintenance Work Practice in Technical College in Ekiti State

\section{Purpose of the Study}

The main purpose of this study was to determine the availability and utilization of physical facilities as correlates of students' academic performance in Electrical Installation and Maintenance Work Practice in Technical Colleges in Ekiti State. Specifically, the study determined:

1. the physical facilities available for electrical installation and maintenance work practice in technical colleges in Ekiti state.

2. the level of technical colleges students' utilization of physical facilities for electrical installation and maintenance work practice in Ekiti State.

3. the academic performance scores of technical college students in electrical installation and maintenance work practice in Ekiti State. 
4. the nature of relationship existing between students' utilization of the physical facilities and their academic performances in electrical installation and maintenance work practice in Ekiti State.

\section{Research Questions}

The following research questions guided the study:

1. What are the physical facilities available for electrical installation and maintenance worksh practice in technical colleges in Ekiti State?

2. What is the level of technical colleges students' utilization of physical facilities for electrical installation and maintenance work practice in Ekiti State?

3. What are the academic performance scores of technical college students in electrical installation and maintenance work practice in Ekiti State?

4. What is the nature of relationship existing between students' utilization of the physical facilities and their academic performances in electrical installation and maintenance work practice in Ekiti State?

\section{Hypotheses}

The following null hypotheses were formulated and tested at 0.05 level of significance:

1. There is no significant difference in the mean ratings of male and female respondents on the level of utilization of physical facilities for electrical installation and maintenance work practice in technical colleges in Ekiti State.

2. There is no significant difference in the mean ratings of respondents on the level of utilization of physical facilities for electrical installation and maintenance workshop practices in technical colleges in Ekiti State based on location (rural and urban).

3. There is no significant relationship existing between students' utilization of the physical facilities and their academic performances in electrical installation and maintenance work practice in Ekiti state.

\section{Method}

This study adopted the descriptive survey and correlational research design. The study was conducted in Ekiti State. The population for the study consisted of 853 (818 students and 35 teachers) of electrical installation in the five (5) Government-owned Technical Colleges in Ekiti State Government. There was no sampling since the population was manageable. Checklist, questionnaire and performance test were used for data collection. The checklist covered availability of physical facilities based on the NBTE Benchmark inventory for instructional resources and contains 4 items.

The questionnaire Titled "Utilization of Physical Facilities in Electrical Installation and Maintenance Workshop Practices (QUPFEIMWP)" was developed by the researcher and was structured on a five-point rating scale of very highly utilized (VHU), highly utilized (HU), moderately utilized (MU), rarely utilized (RU) and Not utilized (NU). The performance test was based on NABTEB standardized tests of 2009 to 2018. As a standardized test, the instrument has already been validated by experts in the field. The NBTE benchmark is a standardized instrument with a reliability index of 0.79 . The reliability of the performance test was determined through splithalf technique and data calculation using Spearman-Brown formula yielded reliability coefficient of 0.905 . The questionnaire was administered with the assistance of five research assistants. A total number of 853 copies of the questionnaire was distributed and retrieved after two weeks and used for data analysis.

Data collected with the checklist were analyzed using frequency count and percentages for research question 1. Any item with 50 percent and above was considered available and below 50 percent was considered not available. The arithmetic mean and standard deviation were used to answer research questions 2 and to determine the closeness of the respondents' means. Pearson Product Moment Correlation coefficient was used to answer the research questions and ascertained the relationship between availability and utilization of physical facilities and students' academic performance in EIMWP. The t-test statistical tool was used to test the null hypotheses relating to utilization of physical facilities at 0.05 level of significance. 
A null hypothesis was rejected where the calculated $p$-value was less than the 0.05 level of significance, it meant that there was a significant difference. Conversely, where the calculated p-value was greater than or equal to the level of significance (0.05). Also, the coefficients of correlation were classified as follows as means of classifying them into the form of relationship they exhibit:
High correlation
$\pm 0.70-1.00$
Moderate correlation
$\pm 0.50-0.69$
Low correlation
$\pm 0.00-0.49$

\section{Results}

\section{Research Question 1}

What are the physical facilities available for electrical installation and maintenance workshop practice in technical colleges in Ekiti State?

Table 1: Frequency and percentage scores of the availability of physical facilities for electrical installation and maintenance workshop practices

\begin{tabular}{lllllll}
\hline S/No & Physical facilities & \multicolumn{2}{c}{ Available } & \multicolumn{2}{c}{ Not available } & Remark \\
& & freq & $\%$ & freq & $\%$ & \\
\hline 1 & Physical facility & 2 & 40 & 3 & 60 & NA \\
2 & Physics lab & 2 & 40 & 3 & 60 & NA \\
3 & Metal workshop & 3 & 60 & 2 & 40 & A \\
4 & Electrical installation workshop & 5 & 100 & 0 & 00 & A \\
\hline & Cluster & $\%$ & $\mathbf{6 0 \%}$ & & $\mathbf{4 0 \%}$ & \\
\hline
\end{tabular}

Data in Table 1 show that only two of the six physical facilities listed are available while the rest are not available for electrical installation and maintenance workshop practices in technical colleges in Ekiti State. The cluster percentage shows that physical facilities are not available with percentage score of 60 against the not available with percentage score of 40 .

\section{Research Question 2}

What is the level of technical colleges students' utilization of physical facilities for electrical installation and maintenance work practice in Ekiti State?

Table 2: Mean and standard deviation on technical college students' level of utilization of physical facilities for electrical installation and maintenance workshop practices

\begin{tabular}{llllll}
\hline S/No & Physical facilities & N & Mean & SD & Remark \\
\hline 1 & Physical facility & 318 & 2.42 & 1.74 & $\mathrm{RU}$ \\
2 & Physics lab & 318 & 2.35 & 1.60 & $\mathrm{RU}$ \\
3 & Metal workshop & 318 & 2.20 & 1.61 & $\mathrm{RU}$ \\
4 & Electrical installation workshop & 318 & 2.82 & 1.78 & $\mathrm{RU}$ \\
\hline & Cluster & $\mathbf{2 . 4 5}$ & &
\end{tabular}

Data in Table 2 show that the cluster mean is 2.45 which indicates that available physical facilities are rarely utilized for electrical installation and maintenance workshop practices in technical colleges in Ekiti State. The 
standard deviations for all the items are within the same range showing that the respondents are not wide apart in their ratings.

\section{Research Question 3}

What are the academic performance scores of technical college students in electrical installation and maintenance work practice in Ekiti State?

Table 3: Range of scores on academic performance of technical college students in electrical installation and maintenance workshop practices

\begin{tabular}{lrrl}
\hline Range of Scores & N & \% & Remarks \\
\hline $0-39$ & 101 & 31.8 & Very Poor \\
$40-49$ & 100 & 31.4 & Poor \\
$50-59$ & 34 & 10.7 & Fair \\
$60-69$ & 38 & 11.9 & Good \\
$70-100$ & 45 & 14.2 & Very Good \\
\hline
\end{tabular}

Table 3 indicates that with scores ranging from 70 to 100,45(14.2\%) of the students have very good performance in electrical installation and maintenance workshop practices in Ekiti State while 38(11.9\%) of the students who scored between 60 and 69 have good performance in electrical installation and maintenance workshop practices.

\section{Research Question 4}

What is the nature of relationship existing between students' utilization of the physical facilities and their academic performances in electrical installation and maintenance work practice in Ekiti State?

Table 4: Pearson $r$ on students' utilization of the physical facilities and their academic performance in electrical installation and maintenance workshop practices

\begin{tabular}{lll}
\hline $\mathbf{N}$ & $\mathbf{R}$ & Remark \\
\hline 318 & 0.61 & High positive relationship
\end{tabular}

Table 4 shows that there is high positive relationship of 0.61 existing between students' utilization of the physical facilities and their academic performances in electrical installation and maintenance workshop practices in Ekiti State.

\section{Hypothesis 1}

There is no significant difference in the mean ratings of male and female respondents on the level of utilization of physical facilities for electrical installation and maintenance work practice in technical colleges in Ekiti State.

Table 5: Summary of $t$-test comparison of the mean ratings of male and female respondents on the level of utilization of physical facilities for electrical installation and maintenance workshop practices in technical colleges in Ekiti State

$\begin{array}{lllllllll}\text { Gender } & \mathbf{N} & \bar{X} & \text { SD } & \boldsymbol{\alpha} & \mathbf{d f} & \mathbf{t} \text {-cal } & \text { P-value } & \text { Decision }\end{array}$




$\begin{array}{llllllllll}\text { Male } & 485 & 2.08 & .11 & 0.05 & 808 & 0.93 & .067 & \\ \text { Female } & 325 & 2.16 & .14 & & & & & \text { Not Significant }\end{array}$

Data in Table 5 show that male and female respondents in technical colleges in Ekiti State do not differ significantly in their mean ratings on the level of utilization of physical facilities for electrical installation and maintenance workshop practices with mean scores of 2.08 and 2.16 while the corresponding standard deviations are .11 and .14. The Table indicated a t-value of 0.93 , at degree of freedom of 808 and a p-value of .067. Testing at alpha level of 0.05 , the $p$-value is not significant, since the $p$-value is greater than the alpha value (0.05). Therefore, the null hypothesis was not rejected.

\section{Hypothesis 2}

There is no significant difference in the mean ratings of respondents on the level of utilization of physical facilities for electrical installation and maintenance workshop practices in technical colleges in Ekiti State based on location (rural and urban).

Table 6: Summary of t-test comparison of the mean ratings of respondents on the level of utilization of physical facilities for electrical installation and maintenance workshop practices in technical colleges in Ekiti State based on location

\begin{tabular}{lllllllll}
\hline Location of institutions & $\mathbf{N}$ & $\bar{X}$ & SD & $\boldsymbol{\alpha}$ & $\mathbf{D f}$ & $\mathbf{t}$-cal & P-value & Decision \\
\hline & & & & & & & & \\
Rural & 520 & 2.16 & 0.14 & 0.05 & 808 & 1.94 & 0.023 & Significant \\
Urban & 290 & 2.08 & 0.11 & & & & & \\
\hline
\end{tabular}

Data in Table 6 show that the p-value of 0.023 is less than 0.05 alpha level and 808 degree of freedom. This implies that respondents in rural and urban technical colleges in Ekiti State differed significantly in their mean ratings on the level of utilization of available physical facilities for electrical installation and maintenance workshop practices. Therefore, the null hypothesis of no significant difference between the two groups was rejected.

\section{Hypothesis 3}

There is no significant relationship existing between students' utilization of the physical facilities and their academic performances in electrical installation and maintenance work practice in Ekiti state.

Table 7: t-test on the relationship between students' utilization of the physical facilities and their academic performances in electrical installation and maintenance workshop practices

\begin{tabular}{lccccc}
\hline $\mathbf{N}$ & $\mathbf{r}$ & Cal.t & df & P-value & Decision \\
\hline 318 & 0.61 & 0.63 & 316 & 0.528 & Not Significant \\
\hline
\end{tabular}

Table 7 shows that at 0.05 level of significance and $316 \mathrm{df}$, the calculated t 0.63 with P-value 0.528 , the first null hypothesis is accepted. Therefore, there is no significant relationship existing between students' utilization of the physical facilities and their academic performances in electrical installation and maintenance workshop practices in Ekiti State.

\section{Discussion of Findings}

Availability of Physical Facilities for Electrical Installation and Maintenance Workshop Practices 
Findings of the study revealed that only two out of four physical facilities were available for electrical installation and maintenance workshop practices in technical colleges in Ekiti State. This means that the facilities are moderately available for enhancing electrical installation and maintenance workshop practices. This finding is in agreement with Joseph and Phillias (2011) who reported that there is low level of provision of physical facilities for teaching Agricultural Science in senior secondary schools in Ekiti State, Nigeria. The result of Joseph and Phillias's study showed that low or inadequate provision of physical facilities in schools would inhibit students' academic performance. This finding is also in agreement with Uzochima (2013) who reported that physical facilities were available but not adequate in the colleges of education. Okoli, Uzogaulu and Okoli (2018) regretted the state of gross inadequacy in the workshop facilities available for instruction in technology education programme in universities of South-east Nigeria.

\section{Utilization of Physical Facilities for Electrical Installation and Maintenance Workshop Practices}

The findings of the study revealed that available physical facilities were rarely utilized for electrical installation and maintenance workshop practices in technical colleges in Ekiti State. The finding is in disagreement with Arum (2015) who reported that physical facilities were utilized for the teaching of Biology education to a moderate level. The study further revealed that almost complete absence of technology, over reliance on obsolete instructional materials and poor method of teaching were the obstacles. The findings of the study also revealed that there was heavy reliance on obsolete instructional materials such as textbooks, model/mock-up, white board, preserved specimen charts and so on. Supporting the above findings, Nwankwo, Nwogbo, Okorji and Egboka (2015) reported that learning facilities for implementing the entrepreneurship education programme in the State were inadequate.

The findings also revealed that male and female respondents did not differ significantly in their mean ratings on the level of utilization of available physical facilities for electrical installation and maintenance workshop practices in technical colleges in Ekiti State. This contradicts the views of Paula (2010) who opined that female business educators are assumed to show lower confidence or knowledge ability than their male counterparts about using various facilities for teaching. This could be as a result of the fact that males tend to be more intrinsically motivated in manipulating physical objects than their female counterparts. The findings of the study also revealed that respondents in rural and urban technical colleges in Ekiti State differed significantly in their mean ratings on the level of utilization of available physical facilities for electrical installation and maintenance workshop practices.

\section{Conclusion}

Based on the findings of this study, it is concluded that the level of availability and utilization of physical facilities for electrical installation and maintenance workshop practices in technical colleges in Ekiti State is not adequate for equipping students with functional practical skills for self-reliance. Therefore, there is need for all relevant stakeholders in technical education programme to ensure that physical facilities are adequately provided and utilized in the teaching and learning of electrical installation and maintenance workshop practices so as to ensure effective acquisition of relevant entrepreneurial skills by the students.

\section{Recommendations}

Based on the findings of this study, the following recommendations were made:

1. Owners of technical colleges in Ekiti State should adequately provide relevant physical facilities for effective teaching of electrical installation and maintenance workshop practices.

2. Administrators of technical colleges in Ekiti State should be encouraged to undertake fund raising activities, the funds of which should be judiciously used to procure adequate physical facilities to enhance effective teaching and learning of electrical installation and maintenance workshop practices.

3. There should be training programmes and skill development for technical colleges teachers that will encourage them to have the requisite skills and exposure to proficiently utilize physical facilities in teaching/learning of electrical installation and maintenance workshop practices. 


\section{References}

1. Akomolafe, C. O. \& Adesua, V. O. (2016).The impact of physical facilities on students' level of motivation and academic performance in senior secondary schools in South West Nigeria. Journal of Education and Practice, 7(4), 38-42.

2. Arum, J. N. (2015). Availability and utilization of instructional materials for the implementation of the new biology curriculum in senior secondary schools in Lagos, Nigeria. Sky Journal of Educational Research, 3(7), 73-86. Retrieved from http://www.skyjournals.org/SJER

3. Babajide, V. F. T. (2010). Generative and predictive-Observe-Explain instructional strategies as determinants of senior secondary school students' achievement and practical skills in Physics. Unpublished Ph.D Thesis, Department of Science Education, University of Nigeria, Nsukka.

4. Eze, T. I, \& Osuyi, S. O. (2018). Effect of problem-based teaching method on students' academic performance in electrical installation and maintenance works in technical colleges in Edo State. International Journal of Development and Sustainability, 7(2), 666-678.

5. Federal Republic of Nigeria (2013). National Policy of Education. Lagos: NERDC Press.

6. Igbo, J. N. \& Vincent, I. K. (2014). Exploring gender relation in the context of collaborative learning and self efficacy of secondary school students Igbo. International Journal of Research in Applied, Natural and Social Sciences, 2(10), 43-54.

7. Joseph, S.O. \& Philias, O.Y. (2011). School facilities and academic achievement of secondary school agricultural science in Ekiti State Nigeria. Asian Journal of Social Science, 7(7), 64 - 70.

8. Lemo, O.O. \& Olakotan, O.O. (2016). Availability and Utilization of Facilities as Correlate of Skill Acquisition in Welding and Fabrication Engineering Craft Practice. African Journal of Education and Behavioural Sciences (AJEBS) 1(1): 182-188.

9. Maduewesi, E. J. (2010). Nursery education in Universal Basic Education. (U.B.E) Scheme. The Nigeria Universal Basic Education, Journal, 1(2), 8-15.

10. NBTE (2007). National Board for Business and Technical Examination Board. Standards and Criteria for Approval of Programmes in Vocational Enterprise Institutions (VEIs) and Innovation Enterprise Institutions (IEls) programmes. Kaduna, Nigeria.

11. Nepal, B. \& Maharjan, R. (2015). Effect of school's physical facilities on learning and outcomes of students in Nepal. Journal for Studies in Management and Planning, 1(6), 266-279.

12. Nwankwo, I. N., Nwogbo, V. N., Okorji, P. N., Egboka, P. (2015). Adequacy of learning facilities for implementing entrapreneurship education programme in secondary schools in Anambra State. International Journal of Innovative Research and Development, 4(9), 1-4. Retrieved from www.jijird.com

13. Nwosu, B. O. (2018). Office management in Nigeria. Benin: Barloz Publisher Inc.

14. Ogbu, J. E. (2015). Availability and Utilization of Instructional Facilities for the Teaching of Basic Electricity in Ebonyi State Technical Colleges. Developing Country Studies, 5(21), 162-168.

15. Ogunleye, A. O. (2002). An Investigation into the Availability and Extent of Resources in the teaching of Physics in some Lagos Public and Private Schools. 47th Annual Conference of STAN.

16. Okoh, S.O. Ayowei, R.W \& Onyeluka .P.O. (2011). Higher education and entrepreneurship education challenges for Nigerian Universities and graduate employment. A publication of centers of entrepreneurial studies, Ajayi Crowther University, Oyo. Pp 13.

17. Okoli , E. I. Uzoagulu, C.U. \& Okoli (2018). Availability and adequacy of Workshop facilities for skill acquisition among undergraduates in technology vocational education in universities in South East Nigeria. Business Education Journal, 1(2), 200-215. 
18. Onokpaunu, M. O. (2016). Analysis of web-based instructional technologies for use by business education lecturers in tertiary institutions in Delta State. Unpublished Master's Thesis, Department of Vocational Education, Nnamdi Azikiwe University, Awka, Anambra State.

19. Oyeyemi, B.N. (2010). Entrepreneurship training in colleges of Education: A necessary tool for selfreliance and sustainable development in Nigeria. A book for readings. NAEP Delta State Chapter. 4653.

20. Paula, P. (2010). Performance measurement practices in small and medium size manufacturing enterprises in Australia. The Journal of Small Business Research 15(2), 10-30.

21. Uzoechima, G. (2013). Availability of physical facilities in colleges of education in South East Nigeria. International Journal of Science and Research, 2(5), 6-14. 